\title{
ANALYSIS OF SPEECH ACTS DURING SPEAKING CLASS AT SMP PGRI 5 DENPASAR
}

\author{
N. L. E. Subagiasih", P. K. Nitiasih", I. G. Budasi ${ }^{2}$ \\ ${ }^{123}$ English Language Education, Post Graduate Program, Universitas Pendidikan Ganesha, Singaraja \\ e-mail: ekasubagiasih0@gmail.com, kertinitiasih@undiksha.ac.id, gede.budasi@undiksha.ac.id
}

This study aimed at and analyzing the types of speech act and the functions of speech act during EFL learning in SMP PGRI 5 Denpasar. The study was designed in the form of descriptive qualitative study which involved an English teacher and eight grade students at SMP PGRI 5 Denpasar. The theory of Searle (1979) was used as the grand theory for analyzing the speech act types and Leech's (1991) was used for the analyzing the function of the speech act. The data were obtained through observing, recording and note taking. The instrument used in this study were researcher (the main instrument), observation sheet, and video recording (the additional ones). The data were analyzed descriptively. The types of speech acts used in EFL learning were directives, representatives, commisisves, expressives, and declaratives category. In EFL learning mostly created speech acts for the competitive, collaborative, convivial, and conflictive function.

\section{Keywords: speaking class, type of speech acts, function of speech act.}

\section{INTRODUCTION}

The uniqueness of the way they speak to each other became the point of interested for the researcher to conduct the research. To getting types of speech acts and the function of speech acts, researcher needs to focus on speaking class at junior high school especially on language used in EFL learning. Thus, the researcher needs to do analysis which concerning in the type of speech act in understanding deep meaning what the speaker said. In addition, this topic of the study is not new. The same topic has been taken by many researcher; however, is does not reduce the important of this study since the researcher concern on the analysis of speech acts in learning process. The researcher analyze what the teacher said and how the students respond based on the theory of speech acts. People communicate they perform action in their utterances, and they are called speech acts (Yule, 1996). In relation to the background study, the research questions can be formulated as follows.1) What types of speech acts express during speaking class at SMP PGRI 5 Denpasar? 2) What function of speech acts used during speaking class at SMP PGRI 5 Denpasar?. Based on the research questions, the purposes of this study are as follows. 1) To analyze types of speech acts express during speaking class at SMP PGRI 5 Denpasar. 2) To analyze function of speech acts used during speaking clss at SMP PGRI 5 Denpasar.

\section{LITERATURE REVIEW}

Searle (1977 in Kess 1993) tried to reformulated the taxonomy of speech acts and others like Wunderlich (1980, in Kess 1993) to criticize the methodologies used in speech act theory. Searle's (1977, in Kess 1993) classifications has five classes of speech acts, but they are different from Austin's work. They are: (1) Representatives like an utterance that describes some state of affairs. For instance "The sun rises in the east" by asserting, concluding, claiming, etc. (2) Directives like order/ command/ dare/ desire which attempt to have a listener to do something. Questions, commands, and requests are all common types of directives. (3)Commissives like promise/ vow/ guarantee/ pledge/ threaten commit the speaker to have some future action. Commissives are utterances that commit the hearer to do something, and include acts like promising, vowing, and pledgeing (Van Dijk, 1997:43). (4) Expressives like thank/ apologize/ deplore/ congratulate express the speaker's effective, psychological state on some matter. Expressives include acts used to express psychological state of the hearer, such as thanking, apologizing, congratulating, and condoling (I'm very sorry to hear that). (5) Declaration is like excommunicate/ appoint/ declare/ christen, as well as some uses of suggest/ 
state/ insist in formalized setting, bring into reality some new state of affairs noted in the proportional content of the declarative. For example, "I hereby appoint you a President". According to (Austin, 1962) theory, there are three aspects of speech acts namely:

\section{a. Locutionary acts}

Locutionary acts are acts of speaking, acts involved in the construction of speech, such as uttering certain sounds or making certain marks, using particular words and using them in conformity with the grammatical rules of a particular language and with certain senses and certain references as determined by the rules of the language from which they are drawn.

b. Illocutionary acts

Illocutionary acts are acts done in speaking (hence illocutionary)), including and especially that sort of acts that is the apparent purpose for using a performative sentence, christening, marrying, and so forth. Austin called attention to the fact that acts of stating or asserting, which are presumably illocutionary acts, are characteristic of the use of canonical constantive, and such sentence are, by assumption, not performatives.

Referring to that, other idea has supported speech acts theory and improved them in several categories such as directives, commissive, representative, declarative and expressive (Levinson, 1985) . Perlocutionary act

Perlocutionary acts are a consequence or by-product of speaking, whether intended or not. As the name is designed to suggest, perlocutions are acts performed by speaking. According to Austin, perlocutionary acts consist in the production of effects upon the thoughts, feelings, or actions of the addressee(s), speaker, or other parties, such as causing people to refer to a certain ship as the Joseph Stalin, producing the belief that Sam and Mary should be considered man and wife, convincing an addressee of the truth of the statement, causing an addressee to feel a requirement to do something, and so on.

Based on (J. . Searle, 1979) of the theory of Speech Act, there are five type of classifications and several functions of each type of these Speech Act. Further, each function leads to a social function for human as social beings. They use Speech Acts in their social interaction.(Leech, 1991) states that at most general level; illocutionary functions may be classified into the following four functions as follow:

Competitive: This illocutionary act aims to the social goal. For instance: ordering, asking, and demanding. In this function, the negative politeness is used to reduce the unpleasant way between what the speakers want to the politeness should say.

Convivial: This illocutionary act aims incompliant with the social purposes, such as offering, inviting, greeting thanking, and congratulating. In this context, the politeness is utilized positively to make a pleasure relationship to the society.

Collaborative: This illocutionary act aims at ignoring the social purposes, such as asserting, reporting, and instructing. This function does not contain politeness.

Conflictive: This illocutionary act aims against the social purposes, for instance threatening, accusing, refusing, and reprimanding. It against politeness that is not at all since it is purposed the anger except in the irony sentence.

There are some researchers who have done researches on the use of speech acts in communicate to the students.

The first research was done by (Altikriti, 2011). The present study was carried out with the aim examining three short stories and analyzes them pragmatically. The theories used for analysis were (Sadock, 1974) and (Green, 1975) who claimed that speech act theory which hypothesizes that there should be a one to one relation between surface form and encoded illocutionary force for direct speech acts meets with unsurmountable difficulties. It has come to the findings that the use of speech acts fluctuate both in quantity and type from one writer to another and from one theme to another. The previous study investigates speech act used in the short stories. In other word, it is text analysis. However, the current study analyzes the speech act used in real world. The analysis focus on the conversation done by the subjects.

The second research was done by Mehus (2006), Mehus also did micro-ethnography research to investigate interaction practices of teachers. This study was done to examine a particular strategy for managing student's behavior in which teacher created interaction and 
physical context for student's actions. But, she explored this phenomenon by using the analogy of "child-proofing", which referred to modifications made to physical environment in order to constrain or enable certain action on the part of children, or to create a context in which the student's actions were likely to become unproblematic. It, then, different with this study in which conduct to know the speech act used by teachers in the interaction to the student in junior high school program.

The third research which also emphasized on the use of speech act to communicate to the student was done by Anggraeni (2010). But, she emphasized that only on the use of one class of speech acts, i.e, directive, by the teachers in teaching and learning process of the young children with special needs. The title of her study was "The Use of Directives by Teachers in Down Syndrome and Austin Class at Sjaki-Tari-Us Foundation, Selat Village, Buleleng. In her research there were four kind of directives used by the teacher namely requesting, questioning, prohibiting, and advisories directives, in giving directives, teachers of Down Syndrome and Austin Class Used verbal directives, sign Language and Pictures techniques because communication was difficult to be understood. Through making the communication visual, with gestures and objects, the children could understand it better. This study also investigates the used of speech acts in teaching and learning process. But, this study is broader than Anggraeni's study which only focused on one class of speech acts. This study is conducted in order to know the other types of speech acts that used by teachers to communicate to students of SMP PGRI 5 Denpasar. Therefore, this study was conducted to know types of speech act are used by the English teacher in their EFL classroom and how effective are the speech act practice English in the classroom.

The fourth research was done by Majid Wajdi (2007) on his research entitled "Speech Acts Produced in Teaching and Learning of English at Senior High School", He had done a qualitative research of speech act at SMA TR Denpasar using the theory of speech act proposed by (Bach, 1979) where they formulate five types of speech acts namely "constative, directives, commisives, acknowledgement, and didactive". The focus of his study is that collecting type speech acts are produces by teacher and students while interacting in teaching activities in the classroom. The total students in the classroom were 20 students. In collecting the data, he used the video recording (70 minutes) to make a sure to be effective for him to get the data as clear as possible. The data than was transcribed into written form to be able to be analyzed into theory of speech act proposed by Kent Bach and Robert Harnish (1979). From the total of speech act found between teachers and students, teacher was more dominant in talking time rather than students so that the occurred of speech act is dominant in a teacher. The function of constatives is assertives, informatives, descriptives, and responsive. Directives serve requstives, advisories, prohibitive. Commisive are functioned as promises and offers. Acknowledgments are used to greet and thank. Didactives serve disputives, descriptive, informatives, and confirmatives.

\section{RESEARCH METHOD}

This study was designed of descriptive qualitative research and this study attempt to investigated the locutionary types of speech acts by the students and teacher during speaking class at SMP PGRI 5 Denpasar; to identify the locutionary function of the speech acts during speaking class at SMP PGRI 5 Denpasar.

According to (Bogdan, 2007), there are four things categorized into qualitative research, namely: (a) natural setting in which the direct source of the data and the researcher is the key instrument, (b) the data were presented in form of words or pictures rather than number, (c) qualitative study concerns on the process rather than simply with products, and (d) the data tend to be analyzed inductively. In relation to those characteristic of qualitative research, in this study has met the natural conversation in classroom interaction. The data were explained descriptively in form of words and they were analyzed inductively.

This study is a pragmatics analysis study since this study is related on the study of speakers suggested by (J. . Searle, 1979) which include representative, directive, commisive, expressive, and declarations. It meaning and it needs to be analyzed as the study of discourse analysis using speech act theory. The focus of this study is to find the types of speech act 
(representative, directive, commisive, expressive, and declarations) types of speech act used by the teacher, and the functions of the speech act used by the teacher.

In doing research, there are three main step done in the research procedure namely: planning, data collection, and reporting. The explanation of the steps will present as follows.

a) Planning

The planning in this study consist of three steps;

1) Making the instruments of the research. The instrument will made observation sheets. There were two observation sheets, the type of speech act and effective of the speech act observation sheets. The instruments made base on the reviewed theories.

2) Establishing the research location. The location which SMP PGRI 5 Denpasar. It is a national school and all of the English teachers are not a native speakers. They are Indonesian native speakers.

3) Arranging research permission. It will explain by asking the letter from the university to be given to establish school. Then, asking the headmaster whether or not the permission is give me.

b) Data collection. Here the data collected used observation sheet and recorder.

c) Reporting. There are two steps in this stage.1) Doing data analysis. Here, descriptive qualitative method of analysis will use to analyze the collect data.

2) Making report. After data analysis, it continued to make the report of the research. When the report will finish, it is consult to the supervisors to be examine.

To obtain the intent data, some instrument used include; observation, recording, and note taking. In details, they are explained as follows;

a) Observation

An observation was conducted by the researcher to the English teacher. The researcher tried to interfere the normal activities in the observation. The observation will focus on the English teachers when they talk with students in their teaching practice.

b) Recording

Type recording was used to record the conversation made by the English teacher with the students when the researcher gained the data. It was useful to help the researcher to categorize the data. The record data then transcribed into the written form in order to enable the researcher to analyze data.

\section{FINDINGS AND DISCUSSION}

After the two techniques were manipulated repeatedly across text types as mentioned previously, the analysis of this experimental research was initially carried out through descriptive Statistical analysis of writing competency of the eight grade of SMPN 2 Manggis based on the experimental group in general and writing competency of each experimental group based on text types. The table analytical data of students' score in writing competency was presented below.

The result of data analysis showed five types of speech acts in EFL learning at SMP PGRI 5 Denpasar. Those were utterances by both teacher and students during the process of learning. Those five types are as follows.

a.) Representatives. The speaker's purpose in performing representative speech is to commit the listener to the belief that the promotional content of the utterance is true. During data observation, the teacher used representative in their communication, types of representative examined was asserting, claiming, affirming, disclaiming, arguing, swearing, and suggesting. The following example illustrates the use of representative in observations. Concerning the utterances above, all of them can be categorized as representatives that are used by teachers in communicating with their students in school within certain context. 
b.) Directives. This speech acts is intended to get the listener to carry out an action. The illocutionary point of directive type of speech act is to try to get the hearer to behave in such a way as to make his/her behavior match the propositional content of the directive. The example of directive verb are order, asking, command, request, question, daring, desire, and defying. Moreover, directive was the type of speech acts that mostly found in the analysis and its frequency. In this situation, the used directive question to students in order to make them interacting actively.

c.) Expressives. These types of speech acts indicate the speaker's psychological state of mind or attitude to some prior action or state of affairs. The example of expressive verbs are: apologize, thanks, congratulate, deplore, condole, welcome, greet, complaint, praise. Expressive type of speech acts was used by the teachers mostly after students responded to teacher' question correctly.

d.) Commisives. These speech act used by the speaker commit the hearer to undertake a course of action as proposed in the utterances promotional content by the person who made the statement. Any commissives utterance is essentially a request to do something and it is not subject to truth conditions since the comment is neither true nor false. Rather it is kept, broken or carry out. The commisives type of speech act obtained in this research represented the form of commisive verb reared to as commit and offer.

e.) Declarative. Declaration type of speech act was used to announce some of students' achievement and approved students' action toward certain activity. Declarative type of speech act was to bring about a change in the word by representing as having been changed. This means that in having something declared successfully, it is expected that they had created a state of affairs.

The functions of speech act produced by students and teachers in speaking class were analyzed using (Leech, 1991), namely; competitive, convivial, collaborative, and conflictive. The result of the observation reveals that the most frequent pedagogical function of speech act used by students and teacher at SMP PGRI 5 Denpasar was collaborative. The proposition of the whole four pedagogical functions of speech act which were proposed by (Leech, 1991). Meanwhile there are four functions of speech acts found during the EFL learning, namely;

a) Competitive. Competitive type was the highest percentage of all types of speech act function. This function is competing the social purpose, such as ordering, asking, demanding, and begging.

b) Collaborative. Collaborative is in different to social function. It is like asserting, reporting, announcing, and instructing.

c) Convivial. Convivial function is coinciding with the social goals such as offering, inviting, thanking and congratulating. This function was found in case of offering, thanking, and congratulating.

d) Conflictive. Conflictive is conflicting the social goal such us threatening, accusing, cursing, and reprimanding, however, this function is only found in teacher's utterance.

Based on the finding above, it can be seen that in teacher's communication, directive type was the most frequent speech act type spoken. By using representative, the teacher could be honest to the student in their communication. Here, the teacher tended to have belief that by asserting, the truth can be confirmed. In doing representative type of speech act, the teacher might not express it as their sincerity but more on stating truth so that the interlocutor can know the truth. It is support by Bjorgvinsson (2011) who states that despite truth conditions, representative speech acts do not depend on the sincerity of the speaker as it is the belief of the hearer that is the marker of wheatear the act is taken as true or false regardless of actual truth.

Directives speech acts were used by teacher and students in EFL learning, according to Yule's theory in 1996, one part of directives speech acts is command. Teacher used command in teaching the student in the classroom. The teacher uttered command expression because of many reason that happened in the classroom.

In terms of commissive types of speech act, the teachers tend to have commitment to a certain undertaking or action. The most frequent type of commissive found was a promise. It 
meant the teacher liked promise on something to the student. The finding of teachers speech act used commissive type, it means that teacher had commitment on what they would do. For example, the teacher promised to check the student's homework. A theory by Crystal (2003) stating that commissive speech act was a type of utterance where the speaker made a commitment to a future course of action. In commissive acts, information was supplied regarding the participants' intention to carry out a future action. It includes promising, pledging, offering, vowing, and swearing. Commissive type was used by the teacher indicating that her try to keep relationship with her students. It can be seen clearly from the example present in the finding.

In terms of expressive, it was also found that teacher produced expressive speech act in their communication in their situation. The teacher tended to be more do congratulating, thanking and apologizing. It means than the teachers used language to keep relationship with their students. The teacher usually gave praise to the student for making student confident in their communication. The student and teacher produced speech act for the function of competitive. According to (Leech, 1983), it aims at the social goal. For instance: ordering, asking, and demanding. Here the teacher produced competitive speech act to the students. It means that teacher tended to achieve social goal. In this function, the purpose of speakers was open competition as a social purpose. It was intended to produce some effects through action by the hearer. This function was frequently belongs to directive.

If it was referred to the theory, the teacher had competitive function. The teacher might want to achieve the social goal i.e. expecting someone to do something. The example taken in finding shows how the teacher directed the students to keep silent. Here, direct utterance was used. It was concluded that to achieve social goal, direct utterance was used by the teacher to make the listener understood easily.

The second most frequent was collaborative. The collaborative function is indifferent social purpose, such as: asserting, reporting, announcing, and instructing. This function frequently belongs to the representative. The teacher produced this function of speech act to the students. It aimed at ignoring the social purposes, such as: asserting, reporting, and instructing. This function does not contain politeness. Reporting is one way how to use speech act as collaborative. In giving instruction, the teacher usually used directness.

The third of most frequent function of speech act is convivial function. The aim is in accordance with the social objectives, such offer, invite, greeting, thank you and congratulate. These tend to be commisive and expressive. (Leech, 1983) states that convivial aims incompliant with the social purposes, such as offering, inviting, greeting, thanking, and congratulating. In this context, the politeness was utilized positively to make a pleasure relationship to the society.

Fourth is conflictive function. Here, the teacher produce it in communication for reprimand their students. That is the reason that the teacher avoid to use utterance that may threaten the hearers. It can also be explained psychologically that the teacher was polite and cared with their student.

Theoretically, Leech (1983) states that the objective of conflictive is contrary to the social purpose. Such as threatening, accusing, cursing and reprimanding. This illocutionary act aims at the social purposes, for instance threatening, accusing, refusing, and reprimanding. It is against politeness that is not at all since it purposed was the the anger except in the irony sentence.

\section{CONCLUSION AND SUGGESTIONS}

Theoretically, the significant effects which were yielded in the present study were as the result of teaching techniques, direct and indirect corrective feedbacks. However, the effect of direct corrective feedback is more effective than indirect corrective feedback on the students' writing competency. This technique gives the students a chance to correct the errors themselves and understand how it should be written in their text. Seiffedin \& El-Sakka (2017) argues that direct feedback is more helpful to writers because it explicitly shows learners what is wrong and how it should be written correctly; minimizing students' confusion over teachers' 
feedback. Therefore, this type is more appropriate for student writers of low proficiency level who do not have the ability to self-correct their errors even when they are marked for them.

Based on the research problems and the data result of data analysis, there are two conclusion can be drawing. They can be describe as follows;

(a) Types of speech acts used in EFL learning are representative, commisive, expressive, and declaration. The most frequent locutionary types speech acts used by the teacher and students during speaking class was directive. The purposes of the speech acts that the teacher used was: 1) to make the students start to focus and listen to the teacher in the classroom; to make the classroom under controlled and direct the student to listen to the teacher's explanation clearly; to make the student care and obey the teachers; to make the students ready for the test and did not ignore teacher's expectation, where the expectations were that the students should finish the work properly and neatly. By using directive speech acts teacher would be easy in monitoring the students; to instruct students, that when teachers were talking the student were not allowed interrupting.

(b) Function of speech acts used in EFL learning are competitive function, collaborative function, convivial function and conflictive function. The teacher and students locutionary acts function mostly create speech act for the competitive function

In accordance on the research problems and the data result of data analysis, there are two conclusion draw. They can be describe as follows. The speech acts used by teacher were mostly to created types of speech acts used by the teacher and students in EFL learning was directive, which are followed by representative, commisive, expressive, and declaration.

The functions of speech acts used by the teacher and students mostly create speech act for the competitive function which followed by collaborative function, convivial function and conflictive function.

Based on the conclusion, there was some suggestion for the teacher, it is suggested to apply direct speech act in instruction process. It aims at making the direction clear for the students. In the classroom teachers should not utter command mostly in instructing the students but also the other kinds of directive speech acts. In many situations, teacher could use request in the classroom activities, where this expression will be more proper behavior. The teacher should be brave enough to organize the classroom by using directive speech acts in the classroom. For the linguists, doing deep research on the area of speech act need to be done especially for the student in multicultural background.

\section{REFERENCES}

Altikriti, S. F. (2011). Speech Act Analysis to Short Stories. Journal of Language Teaching and Research, 2(6), 1374-1384. https://doi.org/10.4304/jltr.2.6.1374-1384

Austin, J. (1962). How to do Things with Words. Oxford University Press.

Bach, K. and R. M. H. (1979). Linguistic communication and speech acts. Cambridge. Mass: MIT Press.

Bogdan, R. . and B. (2007). Qualitative Research for Education. An Introduction to Theory and Methods. Boston: AllynBacin, Inc.

Butler, C. (2012). Powerful Communication - Language - The Key That Opens Or Closes That Important Door. Retrieved from http://ezinearticles.com/?Powerful-Communication--Language---The-Key-That-Opens-Or-Closes-That-Important-Door\&id=5643

Chamani, F. (2014). Gender differences in the use of apology speech act in persian. International Jurnal of Linguistics, 6(6), 46-63.

Goddard, C. (2004). Directive speech acts in Malay (Bahasa Melayu) : An ethnopragmatic perspective. Retrieved from http://praxemaique.revues.org/582

Leech, G. (1983). Principles of Pragmatics. London: Longman. 
Leech, G. (1991). "The state of the art in corpus linguistics", in Aijmer K. and Altenberg B. (eds). English Corpus Linguistics: Studies in Honour of Jan Svartvik. London: Longman, 829.

Levinson, S. . (1985). Pragmatics. New York: Cambridge University Press. 